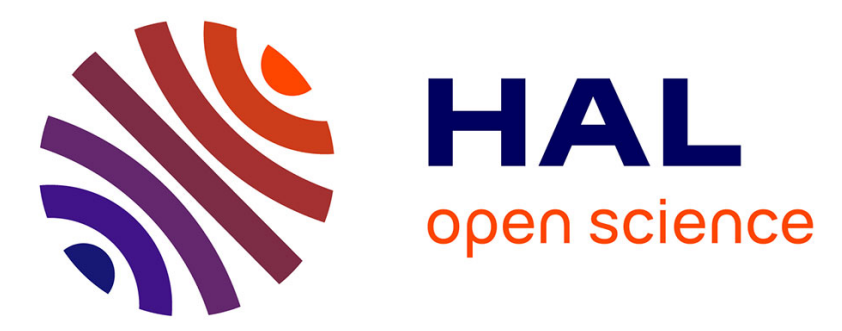

\title{
Tsetse diversity and abundance in Southern Burkina Faso in relation with the vegetation
}

J. B. Rayaisse, E. Salou, S. Kiema, M. Akoudjin, D. Kaba, M. Kagbadouno, V. Djohan, M. Camara, G. K. Dayo, Fabrice Courtin, et al.

\section{- To cite this version:}

J. B. Rayaisse, E. Salou, S. Kiema, M. Akoudjin, D. Kaba, et al.. Tsetse diversity and abundance in Southern Burkina Faso in relation with the vegetation. Parasitology Research, 2015, 114 (9), pp.3357-3363. 10.1007/s00436-015-4560-6 . ird-01224287

\section{HAL Id: ird-01224287 https://hal.ird.fr/ird-01224287}

Submitted on 4 Nov 2015

HAL is a multi-disciplinary open access archive for the deposit and dissemination of scientific research documents, whether they are published or not. The documents may come from teaching and research institutions in France or abroad, or from public or private research centers.
L'archive ouverte pluridisciplinaire HAL, est destinée au dépôt et à la diffusion de documents scientifiques de niveau recherche, publiés ou non, émanant des établissements d'enseignement et de recherche français ou étrangers, des laboratoires publics ou privés. 
Tsetse diversity and abundance in Southern Burkina Faso in relation with the vegetation

J-B. Rayaisse, E. Salou, S. Kiema, M. Akoudjin, D. Kaba, M. Kagbadouno, V. Djohan, M. Camara, G-K. Dayo, F. Courtin, P. Solano, et al.

Parasitology Research Founded as Zeitschrift für Parasitenkunde

ISSN 0932-0113

Parasitol Res

DOI 10.1007/s00436-015-4560-6

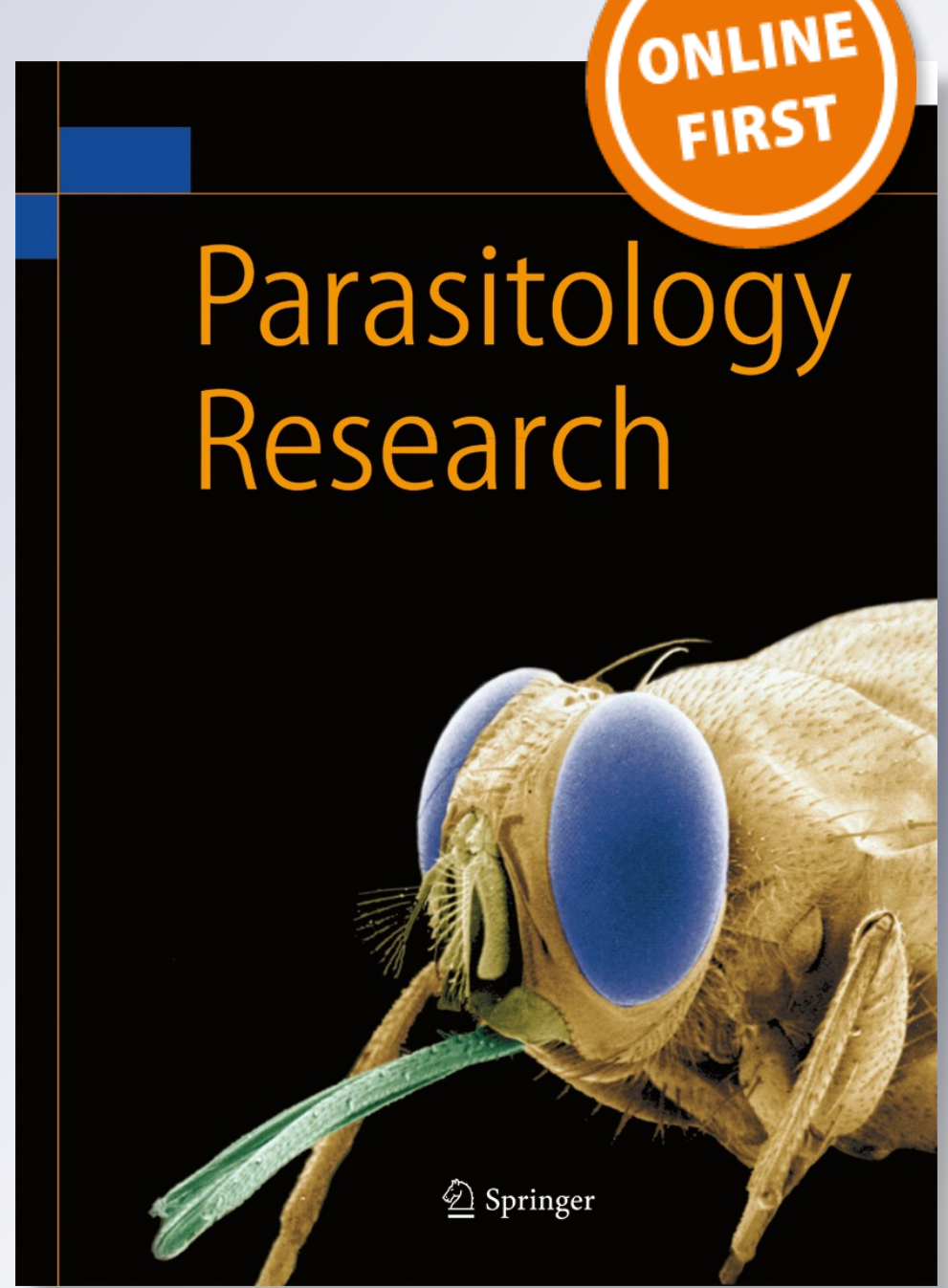

脰 Springer 
Your article is protected by copyright and all rights are held exclusively by SpringerVerlag Berlin Heidelberg. This e-offprint is for personal use only and shall not be selfarchived in electronic repositories. If you wish to self-archive your article, please use the accepted manuscript version for posting on your own website. You may further deposit the accepted manuscript version in any repository, provided it is only made publicly available 12 months after official publication or later and provided acknowledgement is given to the original source of publication and a link is inserted to the published article on Springer's website. The link must be accompanied by the following text: "The final publication is available at link.springer.com". 


\title{
Tsetse diversity and abundance in Southern Burkina Faso in relation with the vegetation
}

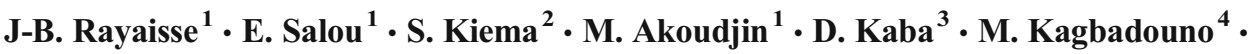 \\ V. Djohan ${ }^{3} \cdot$ M. Camara $^{4}$ - G-K. Dayo ${ }^{1} \cdot$ F. Courtin $^{5} \cdot$ P. Solano $^{6} \cdot$ J. Bouyer $^{7,8,9,10}$
}

Received: 1 March 2015 / Accepted: 27 May 2015

(C) Springer-Verlag Berlin Heidelberg 2015

\begin{abstract}
The increase of human population, combined with climatic changes, contributed to the modification of spatial distribution of tsetse flies, main vector of trypanosomiasis. In order to establish and compare tsetse presence and their relationship with vegetation, entomological survey was performed using biconical traps deployed in transects, simultaneously with phyto-sociological study, on the Comoe river at its source in the village of Moussodougou, and in the semiprotected area of Folonzo, both localities in Southern Burkina Faso. In Folonzo, the survey revealed a diversity of tsetse with 4 species occurring with apparent densities as follows: Glossina tachinoides (8.9 tsetse/trap/day); G. morsitans submorsitans (1.8 tsetse/trap/day); G. palpalis gambiensis (0.6/trap/day) and G. medicorum (0.15 tsetse/trap/day). In Moussodougou, a highly anthropized area, mainly G. $p$. gambiensis was caught (2.06 tsetse/trap/day), and rarely G. tachinoides. The phyto-sociological study allowed discrimination of 6 types of vegetation in both localities, with 3
\end{abstract}

J-B. Rayaisse

jbrayaisse@hotmail.com

CIRDES, 01 BP 454, Bobo Dioulasso 01, Burkia Faso

2 Direction Régionale des Cascades, INERA, Banfora, Burkina Faso

3 Institut Pierre Richet/INSP, 01 BP 1500, Bouaké 01, Côte d'Ivoire

4 PNLTHA, Conakry, Guinea

5 IRD-UMR 177 Intertryp, CIRDES, Bobo Dioulasso, Burkina Faso

6 IRD-UMR 177 Intertryp, Montpellier, France

7 CIRAD, UMR CMAEE, F-34398 Montpellier, France

8 INRA, UMR1309 CMAEE, F-34398 Montpellier, France

9 ISRA, LNERV, Dakar-Hann, Sénégal

10 CIRAD, UMR INTERTRYP, F-34398 Montpellier, France concordances that are riparian forest, shrubby and woody savannah. In Moussodougou, all tsetse were caught in the riparian forest. That was also the case in Folonzo where a great proportion (95 to $99 \%$ following the season) of G. $p$. gambiensis and G. tachinoides were caught in the gallery, while G. m. submorsitans was occurring as well in the gallery as in the savannah, and G. medicorum in the forest gallery. This study showed that although G. tachinoides and G.p. gambiensis are both riparian, they do not have the same preference in terms of biotope.

Keywords Tsetse $\cdot$ Diversity $\cdot$ Vegetation $\cdot$ Comoe $\cdot$ Burkina Faso

\section{Introduction}

Tsetse flies (Diptera/Glossinidae) are constituted by a single genus (Glossina) comprising 31 tsetse species and subspecies, all restricted to sub-saharan Africa. The genus has been divided into three subgenera (or groups) according to external morphologic characteristics, geographical distribution and bioecological factors (Itard and Cuisance 2003). Therefore, we have the fusca group, gathering about 15 species occurring in the forests and thick forest gallery in Central Africa: the morsitan group with 7 species, inhabiting woody savannah all across the continent and the palpalis group (9 species), infesting mainly the dense vegetation along the hydrographical system in West and Central Africa. In this latter, are found the major vectors of both human and animal African trypanosomoses.

The impact of vegetation on the species occurring in Burkina Faso has been described for long, but mainly along the Mouhoun river (Bouyer et al. 2005, 2006; Guerrini and Bouyer 2007; Guerrini et al. 2008; Koné et al. 2011a, b). 
Despite a huge degradation of their habitats, an old theory enacted by Morel (1983) is still valid along the Mouhoun river: Glossina palpalis gambiensis is predominant upstream, in the Guinean riparian forests corresponding to closed tree environments, whereas G. tachinoides becomes predominant downstream, in the more open and bushy Sudanese riparian forests.

The main purpose of the current study was to confirm this pattern in another river basin, the Comoe river. Moreover, we wanted to better characterize the relationship between the different species and how they segregate in their biotope when they occur together in the same area in order to better define their respective ecological niches.

\section{Material and methods}

\section{Study area}

The study was carried out all along the Comoe river in two localities of the Comoe province, southern Burkina in the villages of Moussodougou and Folonzo.

The sites in Moussodougou $\left(\sim 10^{\circ} 49^{\prime} \mathrm{N}, 04^{\circ} 57^{\prime} \mathrm{W}\right)$ were located, on a portion of the Lobi river (which constitutes the source of the Comoe river) where the "small dam" of Moussodougou is built, and also on the Comoe river itself a bit downstream, after the junction of the Koba river (big dam of Moussodougou) and the Lobi river. This area, located in the Turka ethnic group territory, is an agricultural area (sorghum, sweet potatoes, maize, rice, cashew nut, etc.) with a population density of $\sim 35$ inhabitants $/ \mathrm{km}^{2}$.

The second locality was the game reserve of Folonzo $\left(\sim 09^{\circ}\right.$ $\left.54^{\prime} \mathrm{N}, 04^{\circ} 36^{\prime} \mathrm{W}\right)$, southern Burkina Faso. People do not cultivate inside, but wild fauna is currently rare, because of poaching. In this area, $\sim 150 \mathrm{~km}$ still downstream on the Comoe river, four tsetse species occur sympatrically (Rayaissé et al. 2009; Salou et al. 2012). This area, with a population density of $\sim 19$ inhabitants $/ \mathrm{km}^{2}$, is located in the Diula ethnic group territory where people cultivate sesame, sorghum, maize, cotton, cashew nut, etc.

Trials were undertaken in both dry and rainy seasons (December and end of June, respectively, in Moussodougou, mid January and end of May, respectively, in Folonzo).

\section{The entomological survey}

The survey aimed to confirm the presence of tsetse species and consisted in deploying Challier-Laveissière biconical traps in 5 radial transects starting from the immediate bank of the river, going into the savannah (Fig. 1). The 5 transects are separated from each over by a distance of 1.5 to $2 \mathrm{~km}$, while the distance between the different traps of the same transect is about $200-300 \mathrm{~m}$. In total, 25 traps were set for this survey during 5 days at each location and season.

\section{The phyto-sociological survey}

This survey consisted to perform an inventory of vegetation species within a rectangular parcel of $50 * 20 \mathrm{~m}$ for every trap used for the entomological survey. In each parcel, general ecological observations were first done on qualitative data, such as the type of soil, topography, human activities. Quantitative methods were then applied to enumerate vegetal species, and a record on the abundance of each species was attributed, using the scale of Braun-Blanquet (1932).

\section{Data analysis}

From data of the entomological survey, the Shannon index (index of biodiversity) was first calculated within each respective locality, which formula is $\mathrm{H}^{\prime}=\sum_{i=1}^{y}$ pilnpi, where $i$ represents the different species of the area, $p i$ the proportion of a species $i$ out of the total number of species (S) within the area. $\mathrm{Pi}=\mathrm{ni} / \mathrm{N}$, with ni the number of individuals of the species $\mathrm{i}$ and $\mathrm{N}$ the total number of individuals of all the species in the area (Shannon 1948). The calculation was made on one hand for traps set immediately on the bank of the river, and on the other hand for the 20 traps ( 4 traps * 5 transects) set in different level in the savannah to compare biodiversity in the riverine and savannah landscapes. They were assessed for each season.

The aim was to explain tsetse numbers by the following factors: trap distance to the river, season during which tsetse where trapped, tsetse species and their interactions, which were used as fixed effects within a generalized linear mixed model, using a Poisson distribution as a link function (Laird and Ware 1982). Trapping sites were considered as a random effect. The best model was considered as the one with the lowest corrected Akaike information criterion (AICc) (Hurvich and Tsai 1995; Burnham and Anderson 2002).

For the phyto-sociological survey, presence/absence of species within a parcel (site) was noted and coded in a binary way $(0,1)$, then submitted to factorial correspondence analysis. R software was used for all analyses (R Core Team 2014).

\section{Results}

\section{Entomological survey}

In Moussodougou, a total of 343 tsetse flies were caught during the dry season, and 183 (Table 1) during the rainy season by the 25 traps set during 5 days, with a great proportion (97.4\%) of G. palpalis gambiensis.

Most of the tsetse (97.15\%) were caught by the traps deployed along the river bank, except 15 of them (2.85\%) 


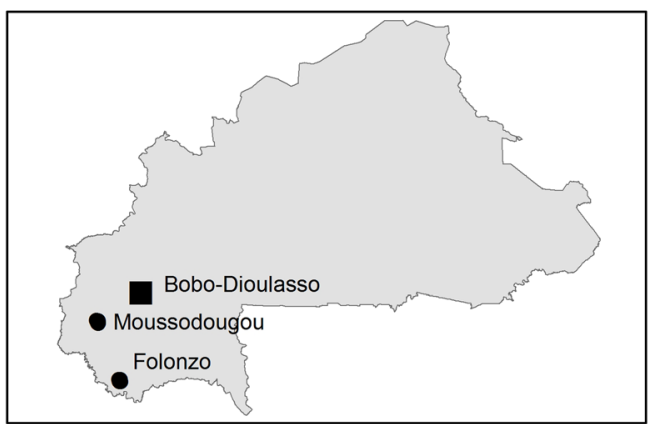

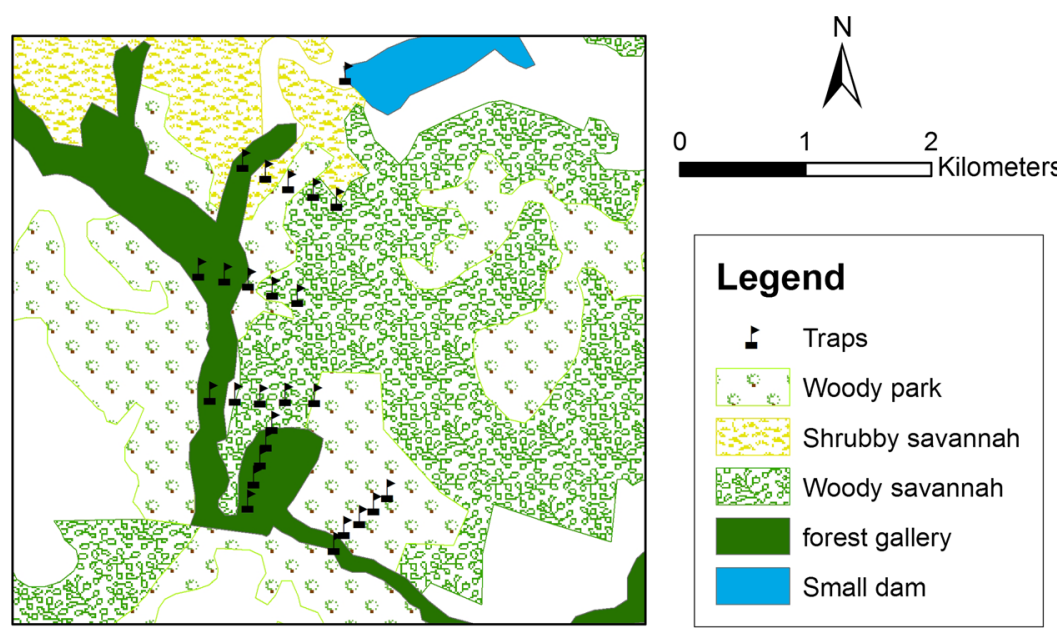

Moussodougou

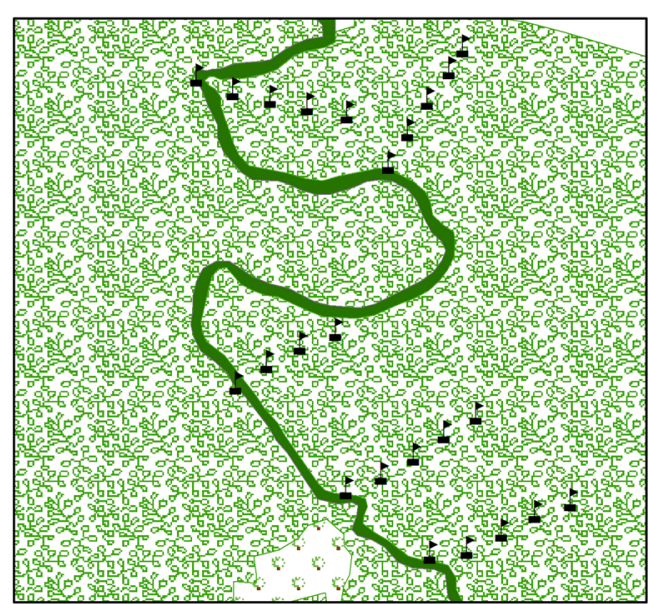

Folonzo

Fig. 1 Traps disposition in Moussodougou and Folonzo along the Comoe River

caught by a trap set on a tributary of a water course, also in the gallery. Therefore, when considering only the traps set in the gallery, daily apparent density of G. p. gambiensis was 12.8 flies/trap/day during the dry season and 7.2 during the wet season, respectively. In this area, the biodiversity was very low during both seasons (Shannon index of 0.11 during the dry season and 0.03 during the rainy season on the fiver bank) and 0 for both in the savannah whatever the season.

In Folonzo, up to 2870 tsetse were caught (41\% during the dry season and $59 \%$ during the wet season), including four species, with $78 \%$ of G. tachinoides, $16 \%$ G. morsitans submorsitans, 5\% G. p. gambiensis and $1 \%$ G. medicorum. Daily apparent densities per species and per season are indicated on Fig. 2 with most of the tsetse caught on the near vicinity of the river. During the dry season, the biodiversity,

Table 1 Total number of tsetse caught in Moussodougou

\begin{tabular}{|c|c|c|c|c|c|c|}
\hline & \multicolumn{3}{|c|}{ Glossina palpalis gambiensis } & \multicolumn{3}{|c|}{ Glossina tachinoides } \\
\hline & Males & Females & Total & Males & Females & Total \\
\hline Dry season & 131 & 203 & 334 & 4 & 5 & 9 \\
\hline Wet season & 101 & 81 & 182 & 1 & 0 & 1 \\
\hline
\end{tabular}

indicated by the Shannon index value, was medium on the immediate vicinity of the river $(0.51)$ and low in the savannah (0.19). During the wet season at the opposite, diversity was low on the riverbank (0.36) and high in the savannah (0.76).

\section{Factors affecting tsetse distribution}

In Moussodougou, only season and tsetse species were considered as factors in the model, as all the tsetse were caught in the gallery all along the river. For the analysis, G. p . gambiensis was considered as the reference species. More tsetse were caught during the dry than the wet season $(p<0.001)$, and G. p. gambiensis was more abundant than G. tachinoides $(p<0.001)$.

In Folonzo, the best model was the one including trap distance to the river, the season, tsetse species and also the interaction between trap distance and the species.

G. medicorum and the wet season were considered as reference categories. Overall, densities were higher during the rainy season $(p<0.001)$ and decreased with distance to the river for all species, but significantly less for $G$. $m$. submorsitans than G. medicorum, and significantly more for G. tachinoides and G. p. gambiensis. 


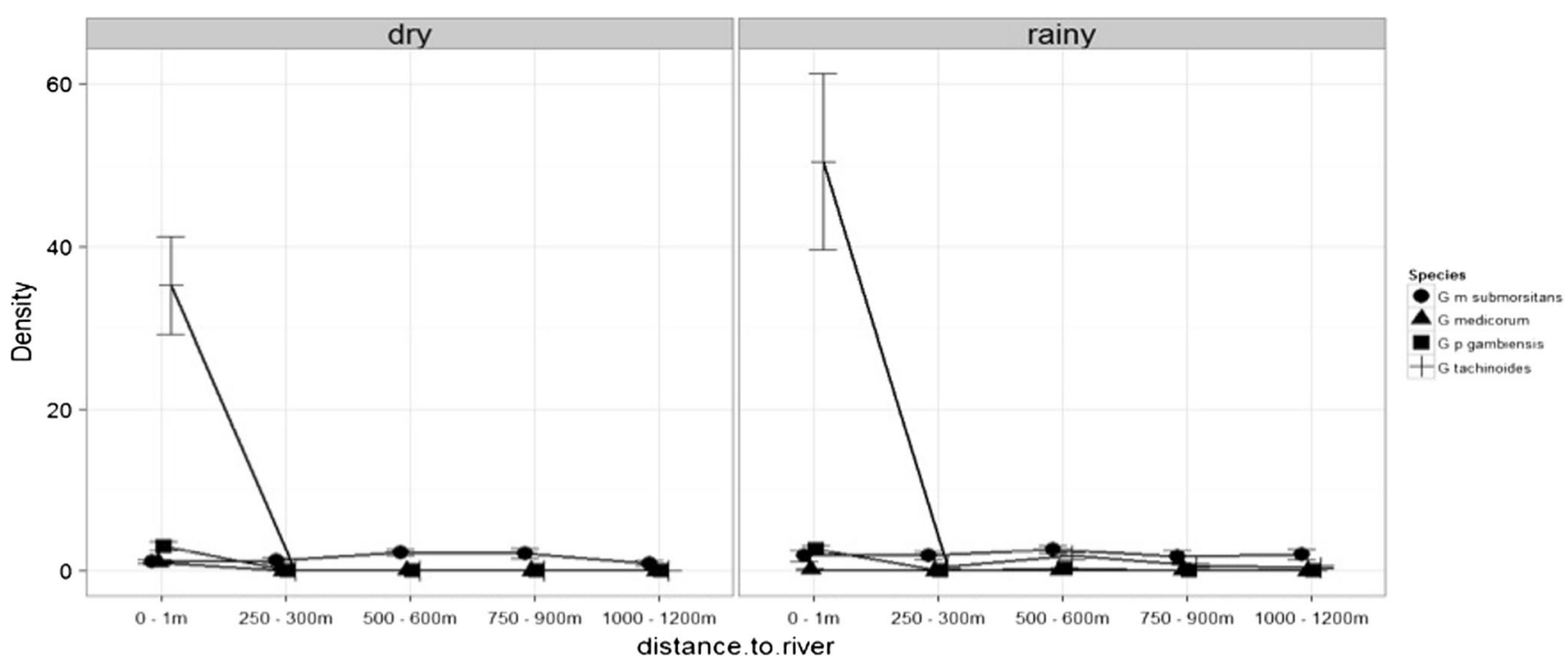

Fig. 2 Seasonal variation of tsetse densities depending on the distance to the river

\section{The phytosociological survey}

In Folonzo (Table 2) as well as in Moussodogou (Table 3), the phytosociological survey established 6 different groups of vegetation.

Vegetation in Folonzo was more conserved, with riparian forest (gallery) along the riverbank, which corresponds to a typical Sudanese riverine forest. When moving through the savannah from the riverbank, there was a succession of forest gallery, clear dry forest, shrubby savannah, shrubby to woody savannah and finally woody,

Vegetation in Moussodougou was more disturbed by human activities. Therefore, one can distinguish (1) riparian forest surrounded by orchards, farms and fallow lands; (2) farms on woody parks; (3) woody parks on fresh fallow land. The three remaining groups were (4) shrubby savannah on old fallow land, (5) shrubby savannah and (6) woody savannah.

\section{Relation between tsetse and vegetation}

Tsetse (mostly G. p. gambiensis) in Moussodougou were caught in the riparian forest, all along the main river or its tributaries. In Folonzo at the opposite, the distribution was depending on the species, and the main one was G. tachinoides. G. tachinoides and G. p. gambiensis mainly prefer the riparian forest (gallery forest), while G. m. submorsitans is found between the gallery and the shrubby savannah and G. medicorum between the forest gallery and the riparian forest (Fig. 3).

Table 2 Types of vegetation in the semi-protected area of Folonzo

\begin{tabular}{|c|c|c|c|}
\hline Number & Type of vegetation & Sites/placette & Dominant species \\
\hline I & Riparian forest & P11, P21, P31, P41, P51 & $\begin{array}{l}\text { Dialium guineense, Syzygium guineense, Manilkara multinervis, Morelia senegalensis, } \\
\text { Cola laurifolia, Berlinia grandiflora (P11, 21, 41, 51) with Mitragyna inermis (Willd.) O.Ktze, } \\
\text { Landolphia dulcis (R.Br. ex Sabine) Pichon in open portions where trees have small size (P 31) }\end{array}$ \\
\hline II & Forest gallery & P25 & $\begin{array}{l}\text { Cola cordifolia, Anogeissus leiocarpus, Tamarindus indica L., Diospyros mespiliformis } \\
\text { Hochst. ex A.DC. }\end{array}$ \\
\hline III & Clear forest & P24, P55 & $\begin{array}{l}\text { Isoberlinia doka, Pterocarpus erinaceus, Afzelia africana Sm. ex Pers., sometimes } \\
\text { associated to Vitellaria paradoxa, Monotes kerstingii Gilg and Burkea africana }\end{array}$ \\
\hline IV & Shrubby to woody & P34, P44 & $\begin{array}{l}\text { Woody stratum: Burkea africana, Erythrophleum africanum (Welw. ex Benth.) Harms, } \\
\text { Daniellia oliveri, Monotes kerstingii Shrubby stratum: Terminalia laxiflora, Terminalia mollis, } \\
\text { Detarium microcarpum Guill. \& Perr., Pteleopsis suberosa, Gardenia erubescens Stapf \& Hutch. }\end{array}$ \\
\hline V & Shrubby savannah & $\begin{array}{l}\text { P12, P14, P22, P23, P32, } \\
\text { P33, P42, P35 }\end{array}$ & $\begin{array}{l}\text { Terminalia mollis, Pteleopsis suberosa, Detarium microcarpum, Combretum adenogonium } \\
\text { Steud ex A.Rich., Crossopteryx febrifuga (Afzel. ex G.Don) Benth., Pseudocedrela kotschyi } \\
\text { (Schweinf.) Harms, Gardenia ternifolia Schum. \& Thon on relative deep soils, with Uapaca } \\
\text { togoensis Pax, Monotes kerstingii and Parinari curatellifolia Planch. ex Benth. on shallow }\end{array}$ \\
\hline VI & Woody savannah & $\begin{array}{l}\text { P13, P15, P43, P45, P52, } \\
\text { P53, P54 }\end{array}$ & $\begin{array}{l}\text { Vitellaria paradoxa, Burkea africana, Erythrophleum suaveolens (Guill. \& Perr.) Brenan, } \\
\text { Anogeissus leiocarpus and Diospyros mespiliformis on sites with old termite mounds }\end{array}$ \\
\hline
\end{tabular}


Table 3 Types of vegetation in Moussodougou

\begin{tabular}{|c|c|c|c|}
\hline Number & Type of vegetation & Sites/Palette & Dominant species \\
\hline I & Riparian forest & P11, P21, P31, P41, P51, P35 & $\begin{array}{l}\text { Riparian forest surrounded by orchards, farms and fallow lands with Berlinia grandiflora, } \\
\text { Uvaria chamae, Carapa procera DC., Khaya senegalensis (Desr.) A.Juss., Anogeissus } \\
\text { leiocarpus, Tetracera alnifolia Willd., Uapaca togoensis, Syzygium guineense, Raphia } \\
\text { sudanica A. Chev., Phyllanthus discoideus (Baill.) Müll. Arg. to which are added } \\
\text { Breonadia salicina (Vahl) Hepper \& Wood in the stream. Some anthropogenic species } \\
\text { (Borassus aethiopum and Anacardium occidentale) are present in the farms and } \\
\text { orchards around the gallery }\end{array}$ \\
\hline II & Farms on woody parks & P43, P44, P45 & Borassus aethiopum and Parkia biglobosa \\
\hline III & $\begin{array}{l}\text { Woody parks on fresh } \\
\text { fallow land }\end{array}$ & $\mathrm{P} 32, \mathrm{P} 42 \mathrm{P} 12, \mathrm{P} 22$ & $\begin{array}{l}\text { Parkia biglobosa, Borassus aethiopum, Vitellaria paradoxa and domestic } \\
\text { fruit species ( Mangifera indica and Anacardium occidentale) }\end{array}$ \\
\hline IV & $\begin{array}{l}\text { Shrubby savannah on old } \\
\text { fallow land }\end{array}$ & P14, P15, P33, P34, P52, P53 & $\begin{array}{l}\text { Terminalia laxiflora, Annona senegalensis, Acacia dudgeoni, Entada africana, } \\
\text { Combretum adenogonium }\end{array}$ \\
\hline $\mathrm{V}$ & Shrubby savannah & $\mathrm{P} 13, \mathrm{P} 23, \mathrm{P} 24, \mathrm{P} 54, \mathrm{P} 55$ & $\begin{array}{l}\text { Acacia dudgeoni, Entada africana, Gardenia erubescens, Terminalia laxiflora, } \\
\text { Combretum collinum Fres., Combretum adenogonium }\end{array}$ \\
\hline VI & Woody savannah & P25 & Daniellia oliveri \\
\hline
\end{tabular}

\section{Discussion}

\section{Tsetse presence and diversity within the two localities}

First, we confirmed that within the riverine species, the sequence observed along the Mouhoun river and described by Morel (1983) is also observed along the Comoe river, i.e. G. $p$. gambiensis is predominant upstream and is replaced by G. tachinoides downstream. While in Folonzo, four tsetse species are occurring sympatrically in relatively high densities, especially for G. tachinoides, G. p. gambiensis is over predominant in Moussodougou, together with a few G. tachinoides. This diversity of tsetse species in Folonzo was already observed (Laveissière et al. 1981; Rayaissé et al. 2009; Salou et al. 2012) and is certainly explained by the suitable ecological conditions, i.e. conserved vegetation and the presence of wild hosts on which tsetse can feed. Particularly, the presence of G. morsitans submorsitans, a savannah species and G. medicorum, a forest one belonging to fusca group, is directly linked to the presence of wild games in the area, including warthogs, hippopotamus, hartebeest, buffalo, Buffon kob, etc. (Rayaisse et al. 2010). Within Folonzo, a big difference has been noted for G. m. submorsitans, being still present in the protected area, but having disappeared in the non-protected one, following disappearance of wildlife (Rayaissé et al. 2009). In Moussodougou, only the vegetation
Fig. 3 Tsetse distribution following the type of vegetation

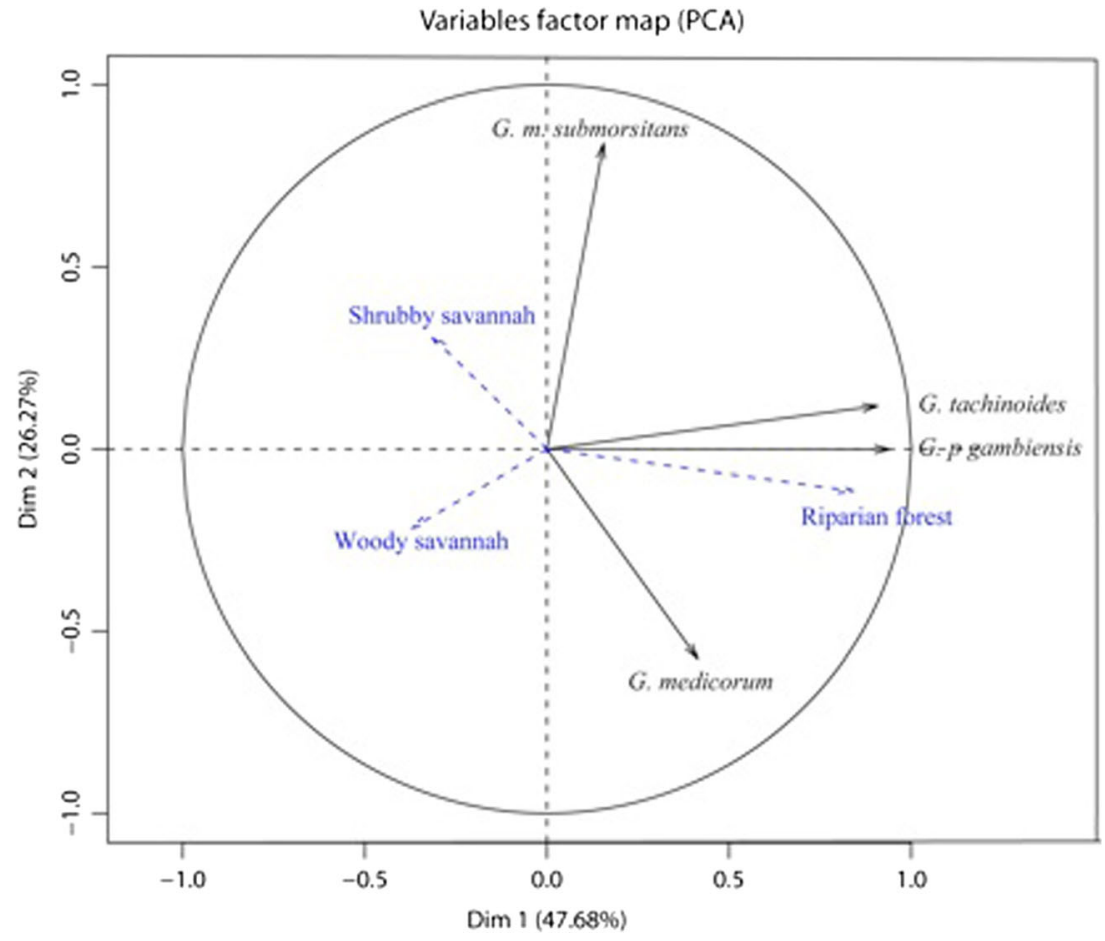


all along the river is preserved, the great part of the savannah having been destroyed by humans for farming purpose. This leads to the disappearance of wildlife, and as consequences the disappearance of G. m. submorsitans and G. medicorum. This confirms other studies (Reid et al. 2000) reporting that G. $m$. submorsitans disappears when human density is over 5 habitants per sq km (Van den Bossche et al. 2010).

\section{The phyto-sociological survey}

Despite that the same number (six) of classes of vegetation were commonly found in both areas, vegetation in Folonzo and Moussodougou is different. Although riparian forest, shrubby and woody savannah were found in the two localities, their specific compositions were not the same.

Moreover, the three other remaining groups of vegetation (farms on woody parks, woody parks on fresh fallow land, shrubby savannah on old fallow) found in Moussodougou only clearly indicate the impact of human action. At the opposite, the fact that the area is protected in Folonzo preserves it from humans for settlement, farming or for hunting.

\section{Importance of water, vegetation and season in tsetse distribution}

The global trend is that tsetse densities decrease when distance from the water increases. This is especially the case for $G$. $p$. gambiensis, which is not caught out from the immediate vicinity of the river. This situation is a normal illustration of the tight link existing between this species with water sources and the vegetation around (Challier 1973; Terrible 1984; Bouyer et al. 2005). G. medicorum neither occurs out from the gallery, but is only found in small humid forests constituted of high trees along the riparian vegetation and called gallery forests, where hosts may be easily found. Although G. tachinoides density drastically decreases from the bank of the river to the savannah, it does not completely disappear in this second area, traducing its capacity to adapt to drier conditions than $G$. $p$. gambiensis. This behaviour also explains why riverine watersheds induce more genetic structuring in G. p. gambiensis than G. tachinoides populations (Koné et al. 2011a, b). Distribution of G. m. submorsitans is homogenous in the savannah, its natural biotope.

Seasonal effects are more visible on the riparian species (G. tachinoides and G. p. gambiensis), which occur only in the gallery, at the near vicinity of the riverbank during the dry season. These species are also caught out of this gallery, although in very low densities. Tsetse are usually more spread in wet season, when suitable climatic conditions (temperature and humidity) can be found everywhere, even out from the gallery (Cuisance et al. 1985), which explains why the indices of biodiversity increased in that area during the wet season.

\section{Interactions between species}

The relationship between vegetation and tsetse densities (Fig. 3) shows that whereas G. medicorum and G. m. submorsitans occupy quite different niches compared to the two riverine species, the two latter co-exist in the same sites. When occurring sympatrically, as in Folonzo, they are probably in competition for hosts (Salou et al. 2012). This is all the more probable than they have a similar host spectrum (de La Rocque et al. 2005) and even bite in the same sites, i.e. the extremities of the legs in cattle, particularly the anterior one (Bouyer et al. 2007). Actually, competition for food has been demonstrated between individuals of the same species (Rogers and Randolph 1984). As a matter of fact, even tsetse of the same species and occurring within the same location may be scattered by sex (Hoppenheit et al. 2013), what may confirm existence of competition within the same species. This is likely to occur between species, since they are linked to a reduction of successful meals with host defence behaviours increasing with the density of the biting flies, which has also been shown for Stomoxys (Torr and Mangwiro 2000). Our results bring further arguments to this hypothesis, since slight differences in the composition of the vegetation of the gallery forest were associated to a clear predominance of one species over the other, suggesting interactions between these tsetse species, in particular competition.

\section{Conclusion}

G. p. gambiensis predominance in Moussodougou confirms that this species mainly occurs in river sources, where vegetation is shaded and the gallery is thin. It also shows that this species can adapt itself to human colonized environment, in opposition to G. morsitans submorsitans. G. tachinoides is dominant in Folonzo along the Comoe River downstream surrounded by an open, wide gallery and adapted open vegetation with presence of wild game as hosts. Presence of G. medicorum and G. m. submorsitans may be explained by the presence of relicts of wildlife and the presence of dense natural forests. These two factors are due to the fact that the area is a protected one, what limited human disturbance (hunting, farming). A next step would be to know what individual vegetal species are preferred by tsetse and to seek if that may be used for vector control purpose.

Acknowledgments We are grateful to Wilfrid Yoni, Issiaka Barry, Fabien Dofini, technicians, and Boureima Sanon driver from CIRDES. We also thank the CIRDES administration for the logistical support and LAMIVECT. This work was funded by the IRD Jeai Ecovectryp Project. 


\section{References}

Bouyer J, Guerrini L, César J, de la Rocque S, Cuisance D (2005) A phyto-sociological analysis of the distribution of riverine tsetse flies in Burkina Faso. Med Vet Entomol 19:372-378

Bouyer J, Guerrini L, Desquesnes M, de la Rocque S, Cuisance D (2006) Mapping African animal trypanosomosis risk from the sky. Vet Res 37:633-645

Bouyer J, Stachurski F, Kaboré I, Bauer B, Lancelot R (2007) Tsetse control in cattle from pyrethroid footbaths. Prev Vet Med 78:223-238

Braun-Blanquet J (1932) Plant Socioliogy. New York

Burnham KP, Anderson DR (2002) Model selection and multimodel inference: a practical information-theoretic approach, 2nd edn. Springer-Verlag, New-York

Challier A (1973) Ecologie de glossina palpalis gambiensis vanderplank, 1949 (diptera-muscidae) en savane d'Afrique occidentale. ORSTOM, Paris

Core Team R (2014) R: a language and environment for statistical computing computer program, version by R core team. R Foundation for Statistical Computing, Vienna

Cuisance D, Février J, Dejardin J, Filledier J (1985) Dispersion linéaire de Glossina palpalis gambiensis et $G$. tachinoides dans une galerie forestière en zone soudano-guinéenne (Burkina Faso). Rev Elev Méd Vét Pays Trop 38:153-172

de La Rocque S, Michel JF, Bouyer J, De Wispelaere G, Cuisance D (2005) Geographical information systems in Parasitology: a review of potential applications using the example of animal trypanosomosis in West Africa. Parazitologiya 47:97-104

Guerrini L, Bouyer J (2007) Mapping African animal trypanosomosis risk: the landscape approach. Vet Ital 43:643-654

Guerrini L, Bord JP, Ducheyne E, Bouyer (2008) Fragmentation analysis for prediction of suitable habitat for vectors: the example of riverine tsetse flies in Burkina Faso. J Med Entomol 45:1180-1186

Hoppenheit A, Murugaiyan J, Bauer B, Clausen PH, Roesler U (2013) Analysis of glossina palpalis gambiensis and glossina tachinoides from two distant locations in Burkina Faso using MALDI TOF MS. Parasitol Res 113:723-726. doi:10.1007/s00436-013-3701-Z

Hurvich CM, Tsai CL (1995) Model selection for extended quasilikelihood models in small samples. Biometrics 51:1077-1084

Itard J, Cuisance D (2003) Vecteurs cycliques des trypanosomoses. In Tec \& Doc (ed) Principales maladies infectieuses et parasitaires du bétail, Paris
Koné N, N'Goran EK, Sidibé I, Kombassere AW, Bouyer J (2011a) Spatio-temporal distribution of tsetse (Diptera: Glossinidae) and other biting flies (Diptera: Tabanidae and Stomoxinae) in the Mouhoun River Basin, Burkina Faso. Med Vet Entomol 25:156-168

Koné N, Bouyer J, Ravel S, Vreysen MJB, Domagni KT, Causse S, Solano P, de Meeûs T (2011b) Contrasting population structures of Two vectors of African trypanosomoses in Burkina Faso: consequences for control. PLoS Negl Trop Dis 5:e1217

Laird NM, Ware JH (1982) Random-effects models for longitudinal data. Biometrics 38:963-974

Laveissière C, Couret D, Kiénon JP (1981) Lutte contre les glossines riveraines à l'aide de pièges biconiques imprégnés d'insecticide, en zone de savane humide. Cah ORSTOM, Sér Entomol Méd Parasitol XIX:41-48

Morel PC (1983) Guide pour la détermination des arbres et des arbustes dans les savanes Ouest-Africaines. IEMVT, Maisons-Alfort

Rayaissé JB, Courtin F, Akoudjin M, César J, Solano P (2009) Influence de l'anthropisation sur la végétation locale et l'abondance des tsé tsé au sud du Burkina. Parasite 16:21-28

Rayaisse JB, Tirados I, Kaba D, Dewhirst SY, Logan JG, Diarrassouba A, Salou E, Omolo M, Solano P, Lehane MJ, Pickett JA, Vale GA, Torr SJ, Esterhuizen J (2010) Prospects for the development of odour baits to control the tsetse flies Glossina tachinoides and G. palpalis s.l. Plos Negl Trop Dis 4(3):e632. doi:10.1371/journal. pntd.0000632

Reid SR, Kruska RL, Deichmann U, Thornton PK, Leak S (2000) Human population growth and the extinction of the tsetse fly. Agric Ecosyst Environ 77:227-236

Rogers DJ, Randolph SE (1984) A review of density-dependant processes in tsetse population. Insect Sci Applic 5:397-402

Salou E, Rayaisse JB, Laveissière C, Sanon A, Solano P (2012) Interactions comportementales et rythmes d'activité de G.p. gambiensis et de G. tachinoides (Diptera : Glossinidae) en galerie forestière au Burkina Faso. Parasite 19:217-225

Shannon CE (1948) A mathematical theory of communication. Bell Syst Tech J 27(379-423):623-656

Terrible M (1984) Essai sur l'écologie et la sociologie d'arbres et arbustes de Haute-Volta. Librairie de la Savane, Bobo-Dioulasso

Torr SJ, Mangwiro TNC (2000) Interactions between cattle and biting flies: effects on the feeding rate of tsetse. Med Vet Entomol 14:400-409

Van den Bossche P, de La Rocque S, Hendrickx G, Bouyer J (2010) A changing environment and the epidemiology of tsetse-transmitted livestock trypanosomiasis. Trends Parasitol 26(5):236-243 